\title{
Public-Service Efficiency Based on Qlue in Jakarta Smart City Development
}

Yusuf Ardianto*
Faculty of Economics and
Business, University of
Indonesia, Jakarta, Indonesia
phoeyusa@gmail.com
Chaikal Nuryakin
Faculty of Economics and
Business, University of
Indonesia, Jakarta, Indonesia
*Corresponding author

Yusuf Ardianto*

Faculty of Economics and Business, University of Indonesia, Jakarta, Indonesia

\begin{abstract}
The purpose of this study is to acknowledge the efficiency level of QLUE application as public-service tool and also as part of Jakarta Smart City development during 2016-2017. The research method was done by applying quantitative approach through descriptivestatistical analysis technique and Data Envelopment Analysis (DEA). The results of the study indicate that Jakarta Smart City development based on information technology, could solve the issues faced by the community and improve public-service. QLUE is one of the application that is being utilized by Jakarta Smart City in receiving reports or people complaints to improve the quality of public-service. Performance efficiency of QLUE in DKI Jakarta showed that the result is still inefficient yet. The whole areas of DKI Jakarta, there were only 74 urban-villages (Kelurahan) shown to be efficient in the performance of public-service based on QLUE during year 2016-2017.
\end{abstract}

Keywords: Public-Services, QLUE, DEA Analysis, Jakarta Smart City

\section{INTRODUCTION}

Constantini and Liberati (2014) stated that globalization has brought massive integration towards developing-countries in the world such as trades, capital-flow, human resources, technology-information for improving those economic condition. The advancement of technology-information becomes basic major for developing a country. In this case, technology-information is often implemented for public-services. Afterwards, the term of "Smart City Development" was born, combining between sustainable city development and Information-Technology (IT)-based on development. Kummitha and Crutzen (2017) stated that "Smart City" has become academic topic that was being widely researched to explain dimensional variations and functions suitability. In Indonesia itself, "Smart City" development has widely progressed in many places, one of these is Jakarta Smart City that is being vastly-evolved among this decade. 
Jakarta Smart City development was established to improve efficiency, creating integrated development, also embracing environmental, social and cultural values inside. The main reason for developing Jakarta Smart City is to empower the role of Jakarta as densely-populated capital, followed by its numbers of issues occured both from economic, social, cultural, and environmental aspects. Govlab (2016) stated that Jakarta, as the capital of Indonesia, is one of the cities with highest urbanization rate in the world and has the highest per capita-income level in Indonesia itself. Ziadi et. al, (2016) stated that Jakarta, as the capital of Indonesia, has the most potential area and has areas with a large population rate, followed by various kinds of issues, especially the growth of quite large urbanization. Impacting Jakarta facing serious issues in many aspects such as security, environmental, energy and also public-service.

Basically, Jakarta Smart City development utilizes three types of information and technology-based application, namely QLUE, WAZE and Map of Jakarta. These applications serve to help society in facing various problems in Jakarta. According to the research of Putri et. al (2017), the business process of Jakarta Smart City program is connected with those three applications, QLUE, WAZE, and Map of Jakarta; which provide communication channels between government and the people; and is considered to be very successful in improving public participation, to contribute in improving the quality of governance. One of the applications that is directly connected to public-service in the process of Jakarta Smart City development is QLUE.

QLUE is an application that works as a media of reporting or public-complaints. With this application, people could report their problems by uploading photos of crime scenes to the government in real time and accurately with the guidance of Global Positioning System (GPS) on their handphones. The reports in this application will be followed up to relevant division by Implementing Unit (Unit Pelaksana/UP) of Jakarta Smart City. Through this application, the follow-ups of those reports could be observed directly by the informant or filer. QLUE is an application that connects people of Jakarta with surround neighbours and employees of Local Government (Pemda), allows people to report the incidents happened surround their environment, by using people participation to solve problems in the city (Putri et. al, 2017). Ziadi et. al, (2016) stated that QLUE and CROP are Smart City applications as information system through social media, collecting people's complaints effectively and revising people participation for the development of Jakarta. 


\section{Data Report $\odot$ qlue}

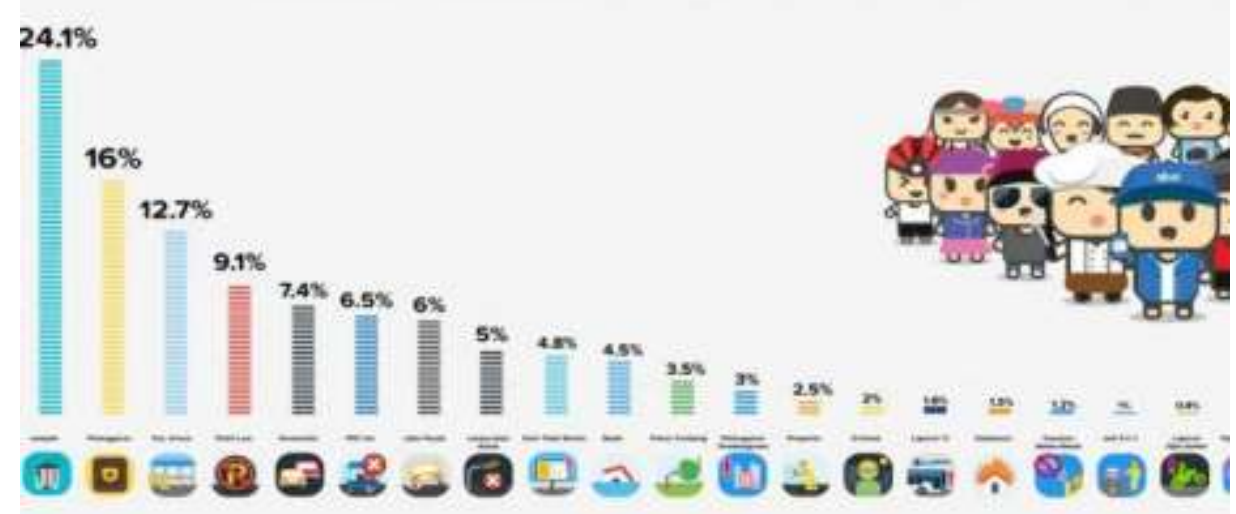

Figure 1. Data Reports input into QLUE in year 2015. From total reports, the 3 big-issues of matters in DKI Jakarta were Waste $24,1 \%$, Violations $16 \%$, and Public-Facilities 12,7\%, followed with Illegal Parking 9,1\%, Traffic 7,4\%, and Illegal Street-Vendors 6,5\%, also some others issues being reported by community.

Ziadi et. al, (2016) had done a research related to QLUE application in Jakarta Smart City development. The research was aimed to measure the effectiveness of information system in public-complaints service based on Jakarta Smart City application by using qualitative-descriptive method. This research stated that in the era of digital governmental, a better technology is needed and used for public interest. Implementation of Jakarta Smart City program is able to influence and help in approaching a desirable public-service. The existence of QLUE as the tool of publiccomplaints is expected to be able to improve the performance of Kelurahan in DKI Jakarta province to be better and accountable. Based on these backgrounds, it can be concluded that the purpose of this research is to measure the efficiency of public-service performance based on QLUE application as part of Jakarta Smart City program.

\section{THEORETICAL REVIEW}

\section{Public-Service Efficiency In Jakarta Smart City}

According to Hartley and Skelcher (in Hartley et al., 2008), public-services holds central role in various aspects of human lives, and also functioning in keeping the existence and the growth of community, nation, and also country. In a sense of definition, Kono and Kishi (2018) stated that in some researches, public-service efficiency was defined as potential project for the enhancement of pareto, where formally are determined with compensation test aiming the measurement of efficiency level. On the other hand, public-service could run efficiently when followed by decentralization. As stated by 
Storto (2016), that the efficiency of public-service could be conducted by implementing the policy of decentralization.

In Indonesia, public-services is regulated by Law. Based on Law Number 25 year 2009, public-service is an activity or series of activities in term of fulfilling the needs of service in accordance with regulations and the needs of every citizen and people towards a product, service, and or administrative service provided by public-service administrator. According to KEPMENPAN Number 63/KEP/M.PAN/7/2003 concerning public-service, the definition of public-service is an effort to fulfil the needs of service recipients or establishment of legislation provisions. While UN (2015) stated that one of attempts to improve social and economic and reduce nowadays gaps, all parties must be survived with the provided public-services mainly to all walks of life, the quality and sustainability of that services have become the main focus to the government.

In carrying out public-service, of course there are some successes and some failures. The successes of government in providing public-services can be seen by the rate of welfares. Successful public-services often followed by the increasing level of community welfares. On the contrary, a failed public-services can usually be seen from the level of community welfare that has not been achieved. Most developing countries have failed to provide public-services. Global Development Network (2009) stated that the failure of public-services in developing countries is not only caused by the scarcity of resources, but also incentive problems, accountabilities, and different management from one context to another. Contextually, the provision of public-services needs various types of innovation, in cooperation with government agents, businessman, NGO, academics, and communities. OECD (2015) stated that knowledge improvement through public-services will adapt knowledge in local context, public-service digitalization, fulfil the needs of individuals, distributed digitally with new social model or organization innovations.

\section{Public-Services Through QLUE Application}

Letter of The Decree of Governor Number 903 year 2016 concerning the mechanism of electronic reports through QLUE application, becomes basic performance of Provincial Government (Pemprov) of DKI Jakarta on implementing Jakarta Smart City program. According to Rahmawati and Firman (2017), QLUE application is a new breakthrough of Pemprov DKI Jakarta as a forum for the community to report any kinds of problems such as traffics, waste, floods, violations, fires, damaged-roads, beggars, illegal streetvendors, crimes, broken street-lights, fallen trees, public-facilities, illegal parking, violation in building-permits,non-smoking areas, and other kinds of troubles. Meanwhile, Putri et. al, (2017) said that QLUE is an application that connects Jakarta residents with surrounding neighbours, and also employees of regional government, allowing them to report the incidents happened in the environment, using people's participation to solve the problems in Jakarta. Supported by Oostveen and Besselaar (2004), said that 
introduction of digital technology, such as social-media in public-service has been combined to create innovative ability for government and interactive people.

\section{METHODOLOGY}

This study used quantitative approach with descriptive statistical analysis techniques applied to analyze the development of reporting and Data Envelopment Analysis (DEA) to measure efficiency. The study took data of 5 administrative regions in DKI Jakarta Province, those are South Jakarta, West Jakarta, East Jakarta, North Jakarta, and Central Jakarta. While the period of data taken in the study started from 2016-2017. In more detail, this study used an intermediation approach with the Constant Return to Scale (CRS) model to analyze input and output variables.

There are two types of variables in this study, which are divided into input and output. Variables belong to input include the number of complaints through QLUE application as a reference from QLUE application, the effective budget resources of that Kelurahan itself per end of the year, employees of Kelurahan and Municipal Police (Satpol PP), and Public Infrastructure and Facilities Officer (PPSU) of Kelurahan.

$P(x i . . ., c)=$ (Officers of Satpol PP, Regional Government Budget (APBD) of Kelurahan, employees of Kelurahan, number of PPSU officers)

Furthermore, the variable that belongs to the output is the complete status of people complaints in the QLUE application from each Kelurahan. Besides that, this status is classified into 11 biggest types of complaints, those are waste, violations, illegal parking, public-facilities, traffics, damaged roads, illegal advertising, broken street-lights, illegal street-vendors, floods, fallen trees, and other reports after being filtered from the obtained data by UP Jakarta Smart City.

$P(x t)=$ (complete status from category of waste, violations, illegal parking, public facilities, traffics, damaged roads, illegal advertising, broken street-lights, illegal streetvendors, floods, fallen tree, etc.).

From those two groups of variables, then it can be formulated into an efficiency equation with the following efficiency values:

$P(x, c)=P(x i \ldots ., c)$

$P(x t)$

(Pendhakar, 2018)

The complaints category is divided into 12 community complaints in QLUE application, which are:

1. Floods,

2. Public facilities,

3. Illegal advertising,

4. Damaged roads, 
5. Illegal street-vendors,

6. Traffics,

7. Broken street-lights,

8. Illegal parking,

9. Violations,

10. Falled trees,

11. Waste,

12. others.

Those complaints are redivided into 3 statuses in the follow-up, among others are: (1) wait, which means that there is still no process from the government, both urban-village and sub-district, (2) process, which means that the reports have been responded to and is being processed by each respective officers, and (3)complete, if the issues have been resolved. Therefore, the people could easily observe the problems they are facing in QLUE application.

\section{RESEARCH RESULTS}

Advances in information technology (IT) innovation are currently not only be used In private sector, but also in public-service institutions that are used to radically improve service quality (Kamal, Vishanh, \& Zahir, 2010). As a "Smart City", Jakarta utilizes various types of applications resulted from IT innovations on improving public-service to the society. QLUE becomes one of application to accommodate people's aspiration. However, in the end of 2017 there were still less users using QLUE application to file a report to the government compared to the total amount of Jakarta's residents. From 2016-2017 the number of population in Jakarta had reached more than 10 millions people. Based on the reports submitted into QLUE, there were only hundreds thousands of people that had made the complaints or around $2-4 \%$ of the population that had used this application. Fitriani et al (2016) stated that the number of people who submitted complaints through QLUE application was very few compared to the total number of people in Jakarta. The main cause was due to the society behavior problems when using QLUE facilities.

During 2016, there were 478.492 files of complaints reported in QLUE facility. However in 2017, these were decreasing into 228.119 reports only. 2016-2017 are transition years due to the replacement of DKl's governor, leading to the change of program and development of vision and mission as smart city. During the transition, the old structure was reopened, through direct-complaint system in Kelurahan to Kecamatan (Subdistrict). This is the main reason for the decreasing number of public-complaints through QLUE application. Based on monthly data, the highest level of public complaints is seen in early months (January-March) of the year and would keep decreasing until the end of 2017. 


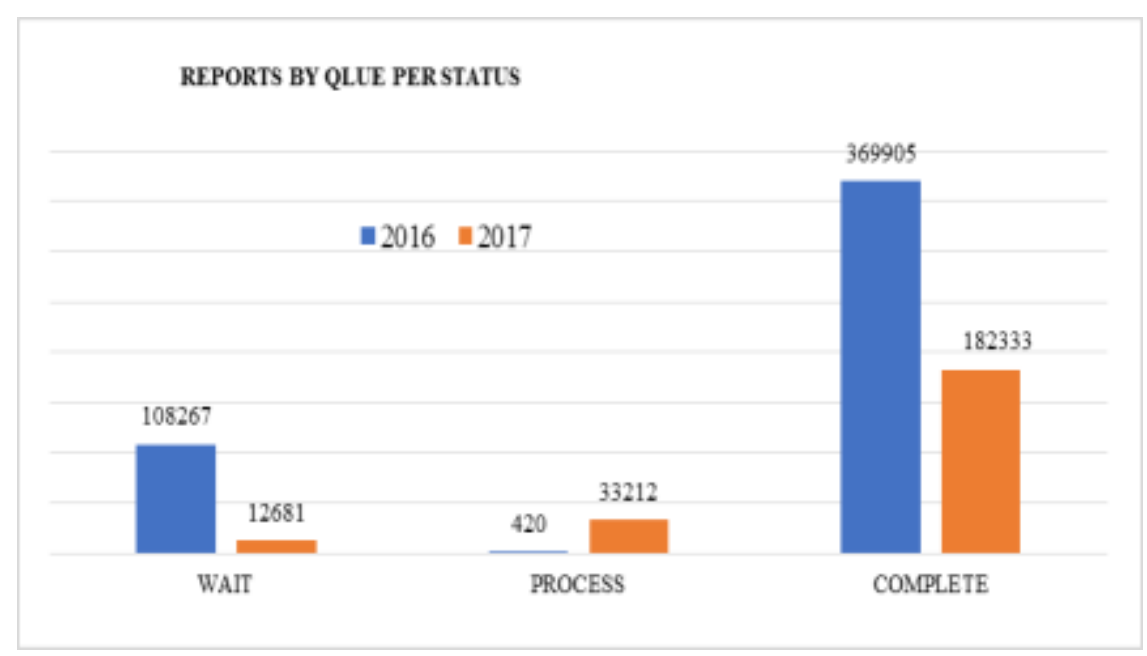

Figure.2 Reports of Complaints with QLUE Based on Status

Although there had been a declining in reports, however based on the data on complaints per status, it is still dominated by completed reports or is called "complete". In other words, people's reports could be well-done solved by the government of DKI Jakarta. Complaints that have achieved "complete" status reached 369.905 out of a total of 478,492 complaints or $77.3 \%$ of total complaints, were resolved in the period of 2016. The number that had been resolved had increased by almost $80 \%$ than the following year. The data illustrates that with QLUE application, the government could move quickly to solve the issues faced by the society. Nevertheless, it was still lacking on the number of people filing reports based on this technology. The government has not been optimal in socializing or educating the people of DKI Jakarta to be able to report public issues by using this application.

On the other hand, there were more reports with "wait" status, which were 108.267 reports, compared to "processed" status, which were only 420 reports. It showed a delay in processing the reports. Further analysis from this report was the focus of DKI Jakarta government towards easily-solved problems, to make complete status finished compared to the reports in process. There were many factors causing this problem to be occured ("wait" status), including: lack of human resources to work with the reports, the complaints were non-priority one, or the complaints caused less major-impacts to the people so that the government of DKI Jakarta preferred to process urgent reports with more major-impacts.

The government of DKI Jakarta improved those conditions in order to have fewer reports on wait position compared to the reports on process position in 2017. There were only 12.681 reports/complaints on wait, and 33.212 reports on "process". In conclusion, the process of public-services was accelerated during the period of 2017, though the reports number was decreasing significantly. 
System of decentralization has important role to regional government (Pemda), causing Pemda holds full responsibility towards the system and policies of public-services. However, the position of society still holds the key element of public-services. Therefore, collaboration and correct intermediation element between government and the society are needed. By the research of Rondo Brovetto dan Salitere (2007), was stated that regional government is the main player in the act of public-service reformation, while the local community are the key element of organization and management of that regional government.

Hence, on the issue of IT-based public-service standards, government of DKI Jakarta is a major player in public-services and the community is an important element of the system. The community acts as the served-party and the party who complains. With QLUE system, the government will work to serve the community based on complaints in the application. Van Schalkwyk et al, (2017) stated that a set of data used by DKI Jakarta government extensively was the data of reports or complaints collected by QLUE and together the community is able to watch the progress of the reports. Thus, there is a "check-and-balance" between the performance of government public-services and the community served.

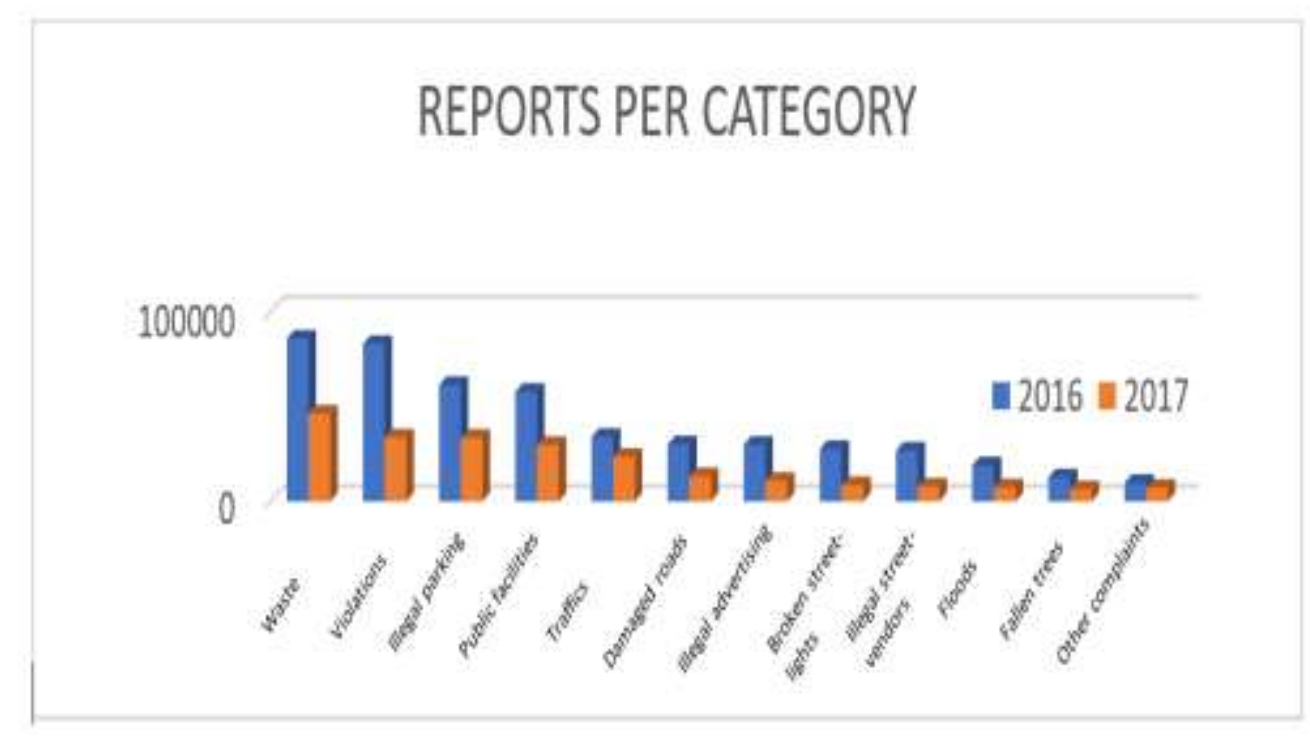

Figure 3. QLUE reports per category

Based on complain categories, the most reported complaints by the community in 2016 and 2017 were waste. Waste or garbage become the most disturbing problems for the people of DKI Jakarta. During 2016 there were 86.045 complaints concerning waste. While during the period of January to December 2017 there were 46.339 complaints concerning waste. The next highest-rank category of complaints was the violations of prevailing regulations and laws. There are still many people of DKI Jakarta who do not obey the regulations or violate the applicable regulations, both written and unwritten. Apart from these two problems, there are still the problem of illegal parking, 
inappropriate uses of public facilities and traffic issues that still worried the people. The community demands regional government to immediately solve those problems. Public facilities, illegal advertising, broken street-lights, illegal street-vendors, floods, and fallen trees are also still becoming disturbing issues for the activities of the people in DKI Jakarta.

Basically, DEA method allows the calculation of efficiency technically as measured by both input and output. The main purpose of this method is to evaluate the amount of input quantity which can be proportionally reduced without any change in the quantity of output (Afonso dan Scaliogoni, 2005). The results of DEA in this study indicate the magnitude of efficiency of each Kelurahan in providing public-services within DKI Jakarta's government. DEA analysis in this study consisted of the DEA to measure yearly efficiency and DEA to measure efficiency in data panel or per Kelurahan. Analysis results of both methods indicate the declining level of public-services efficiency in area of Kelurahan DKI Jakarta in 2016-2017.

Table 1. Maximum and Minimum Rates, and Average Efficiency of Data Panel

\begin{tabular}{llll}
\hline & Maximum & Minimum & Average \\
\hline 2016 & 1 & 0.100217865 & 0.854717396 \\
2017 & 1 & 0.05217 & 0.57405 \\
\hline
\end{tabular}

Based on the analysis results of average rates in the panel, the efficiency of Kelurahan in 2016 was still 0.85 but there was a declining in the average efficiency in 2017 into 0.57. This large number indicates that there has been a declining in efficiency of almost $50 \%$ from the previous period. The same thing happened based on the minimum rate of efficiency. In the period of 2016, minimum rate of efficiency reached 0,1 , while on the next period minimum rate of efficiency only reached 0.052 , decreasing almost 0.05 from previous period. This indicates that the performance of public-service in Kelurahan based on QLUE application had become more inefficient in 2016-2017.

In the case of efficiency, the maximum rate is 1 (one) which means that Kelurahan has done efficient work in public-services towards the people. Analysis results of DEA with the method of 2016-2017 data panel, indicate that the efficiency average rate of whole Kelurahan is 0.71 while minimum rate is 0.052 . In average, data panel for Kelurahan in DKI Jakarta are not efficient yet in providing public-services with QLUE application. Many factors hinder technological progress in terms of public services which causes the government to be unable to improve its performance efficiency. One of those is the culture of people who are still unfamiliar with the how-to-use QLUE application-based-on public services. The following is the result of the analysis of the 2016-2017 DEA efficiency data panel. 
Table 2. Maximum and Minimum Rates, and Average Efficiency of Public-Services

\begin{tabular}{cccc}
\hline \multirow{2}{*}{ Years } & \multicolumn{3}{c}{ Efficiency of Public-Services } \\
& Maximum & Minimum & average \\
\hline 2016 & 1 & 0.100217865 & 0.8547174 \\
2017 & 1.00000 & 0.05217 & 0.57405 \\
\hline
\end{tabular}

Furthermore, the results of statistical analysis also indicate the same matter, that is a decrease in the level of efficiency based on the number of kelurahan that are categorized to be efficient. In the period of 2016, there were 148 kelurahan that reached efficiency rate 1 for the performance of public-services based on QLUE application. In the next period of 2017, there were 46 Kelurahan remained that reached efficiency rate 1 on public-services with QLUE application. In 2016, there were no Kelurahan reached minimum rates of efficiency below 0.1. There were 4 Kelurahan that reached efficiency rates $0.1-0.19$. Meanwhile in 2017, there were 5 Kelurahan that reached efficiency rates below 0.1 .

Meanwhile what is seen in the data panel, in general there were 84 kelurahan that reached the same efficiency rates for the last 2 years. There were 75 kelurahan reached efficiency rates 1 for 2 years in a row. From there, it can be seen that the 75 urban villages have served their communities based on the performance of the QLUE application efficiently for the last 2 years.. There was only 1 kelurahan that reached efficiency rates about 0.9-0.99. There were 2 kelurahan that reached efficiency rates 0.8 0.89. On each, one kelurahan reached efficiency rates 0.7-0.79; 0.6-0.69; and 0.2-0.29. While the remaining 3 kelurahan reached efficiency rates in the range of 0.4-0.49.

As being seen based on the percentage in $2016,56.70 \%$ of kelurahan have served the community efficiently with the performance based on QLUE application. However, it was decreasing in 2017 , remaining only $17.62 \%$ of total kelurahan categorized as efficient in serving the community. Based on the processed results of DEA in 2016, only $9.6 \%$ of kelurahan that reached an efficiency rates below 0.5 . Meanwhile in the following period, $48.7 \%$ of kelurahan received efficiency rates below 0.5 . Based on the number of input consisted of the number of Satpol PP members, budgets per kelurahan, the number of PPSU, and the number of employees of kelurahan, over the past two years had increased. However the number of output which is the solved-reports had drastically decreased. Those were the cause of the decreasing efficiency rates during the last two years. There were only 11 kelurahan that the efficiency rates were increasing from 2016 to 2017. So that there are 166 urban villages that have decreased the level of efficiency during the last two years. Hence, there were 166 Kelurahan encountered a decrease of efficiency rates for the last two years. 
Table 3. Number of Kelurahan based on Efficiency Rates

\begin{tabular}{crrr}
\hline Efficiency Rate & \multicolumn{4}{c}{ Years } \\
1 & $\mathbf{2 0 1 6}$ & $\mathbf{2 0 1 7}$ & $\mathbf{2 0 1 6 - 2 0 1 7}$ \\
\hline$>0.9-0.99$ & 148 & 46 & 75 \\
$>0.8-0.89$ & 17 & 13 & 1 \\
$>0.7-0.79$ & 18 & 19 & 2 \\
$>0.6-0.69$ & 18 & 23 & 1 \\
$>0.5-0.59$ & 19 & 22 & 1 \\
$>0.4-0.49$ & 16 & 16 & 0 \\
$>0.3-0.39$ & 12 & 35 & 3 \\
$>0.2-0.29$ & 4 & 37 & 0 \\
$>0.1-0.19$ & 5 & 35 & 1 \\
$0.00-0.99$ & 4 & 15 & 0 \\
\hline
\end{tabular}

If seen based on the percentage, the kelurahan that reached an increase in efficiency rates were only about $36.4 \%$, while $63.6 \%$ of kelurahan encountered a decrease of efficiency rates. And the rest $32.2 \%$ of kelurahan had the same rates over the last two years. It means that the efficiency of Kelurahan performance is dynamic and could change over time. It depends on how the inputs respond to the outputs. In the case of public-service performance of kelurahan in DKI Jakarta, the decrease occurred caused by the decreasing outputs and the increasing inputs. The excess of input was not followed by an increase in output, so the value of the efficiency level is drastically decreased.

Table 4. Slack Rates of Input of Analysis of DEA

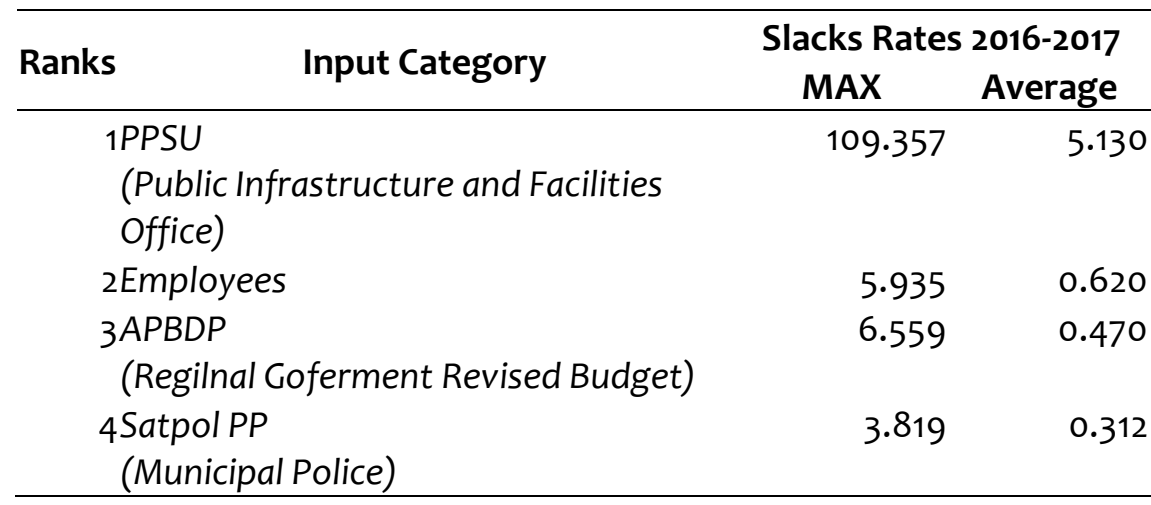

Detail analysis of efficiency by using DEA method can be seen from the slack rates of each kelurahan and each input-output rate. Slack rate indicates the formation of efficiency rates by substracting input or adding output. Based on the DEA analysis in general, indeed the efficiency in 2017 need to substract the input and add the output. There were only some kelurahan that did not necessarily need a decrease of input or an increase of output, over the last two years. Thus, these results emphasize the outcomes of efficiency rates that there has been a decrease of efficiency level in the performance of public services in Kelurahan of DKI Jakarta, in 2017. 
Table 5. Slack Rates of Output of Analysis of DEA

\begin{tabular}{cccc}
\hline \multirow{2}{*}{ Ranks } & Output Category & \multicolumn{2}{c}{ Slacks Rates 2016-2017 } \\
& MAX & Average \\
\hline 1 & Waste & 1280.149 & 95.277 \\
2 & Violation & 575.499 & 71.990 \\
3 & Public Facilties & 504.077 & 44.447 \\
4 & Illegal Parking & 373.730 & 37.289 \\
5 & Traffics & 473.185 & 32.637 \\
6 & Illegal Advertising & 583.872 & 31.503 \\
7 & Damage Road & 231.116 & 22.359 \\
8 & Broken Street-Lights & 216.507 & 21.643 \\
9 & Illegal Street-Vendors & 196.709 & 19.108 \\
10 & Floods & 201.830 & 14.464 \\
11 & Fallen Trees & 101.963 & 9.518 \\
12 & Other Complaints & 107.691 & 5.667 \\
\hline
\end{tabular}

Based on the slack rates on input variable, the main factor that causes the inefficiency of kelurahan performance in responding people complaints through QLUE application, is the number of PPSU. In other words, addition to the number of PPSU, is very inefficient in responding the output. The highest rate of input slack is 109.3 for PPSU. Meanwhile, the output that contributes to the inefficiency of public-service performance in kelurahan is waste-handling. Meaning, there are still many unfinished complaints of waste, so it is necessary to enhance government performance in overcoming waste problem.

Aside from the number of PPSU, based on input-output analysis, there are number of employees, amount of APBD allocation, and number of Satpol PP, that need to be reduced. For the output that must be added, among others are waste, illegal advertising, general violations, public facilities, and traffics. Thereby, government of DKI Jakarta need to evaluate the number and performance of PPSU, employees of kelurahan and Satpol PP in handling waste problems, illegal advertising, violations, and traffics. Number of personnel on input is not compatible to the number of issued output, therefore synchronization between input and output is required.

Kelurahan with perfect efficiency rate 1, then the rates of slack in input and output are 0. It is because neither the input nor the output has advantages or disadvantages. The poin is, the input and output are in balance, resulting the slack rates of input and output of those kelurahan are 0 . While the inefficient kelurahan will have good slack rates in input or output. For example, in Kelurahan of Ancol in 2016, performance efficiency of QLUE showned efficient result, pointing slack rate in 0 . While in 2017, efficiency rates were decreasing caused by the lack of APBDP, PPSU, and employees. On the other hand, there were also more number of waste, violations, illegal parking, public facilities, 
traffics, damaged roads, broken street-lights, illegal street-vendors, floods, and fallen trees.

Thus, APBDP, number of PPSU, and employees hired in Ancol Kelurahan, were insufficient to handle the problems of waste, violations, illegal parking, public facilities, traffics, damaged roads, broken street-lights, illegal street-vendors, floods, and fallen trees. For solution, the government of DKI Jakarta needs to add more APBD, more number of PPSU, and also employees in Kelurahan of Ancol in order to handle all people complaints for those issues. Employees are essential element on improving publicservice. In Norway, employee's professionalism is required to improve effectiveness and efficiency in public-service. In the era of digital that is applied to public-service, government workers must focus on how the technology itself supports their performance (Bush et.al, 2018).

In Taiwan, the role of government is very important in improving public-service efficiency, in the context of smart city. Government can use social media application to fulfil the needs of the people. However, to improve efficiency and effectiveness of this application, sufficient personnel and budgets are required (Yeh, 2017). Likewise, what happened in Jakarta Smart City, the effectiveness and efficiency of QLUE application performance also require supports from the number of personnel responded to complaints and sufficient budgets. Kelurahan of Kebon Kacang possessed the lowest efficiency rate in 2016 and 2017. It was generated by the lack of Satpol PP, APBDP, and number of employees in Kelurahan of Kebon Kacang in the performance to respon people complaints. If the budgets, number of Satpol PP and employees of kelurahan were added, then Kelurahan of Kebon Kacang would be way more efficient in handling people complaints. Results of DEA discovered that the rate of Satpol PP in Kebon Kacang was only 0,04, while the average rates of whole kelurahan is 0.25 . Therefore, additional number of Satpol PP in Kelurahan of Kebon Kacang can offset the average rates of whole Kelurahan in DKI Jakarta province. The rate for APBD is only 0.21 . While the average rate of APBD is 0.71 , in that case it needs an addition of 0.5 to reach average rates of APBD in DKI Jakarta Province. For the rate of employees, Kelurahan of Kebon Kacang reached 0.38 , while the average rates among whole Kelurahan in Indonesia is 0.62. Therefore, an addition to the number of employees is required to reach average rates of whole kelurahan in DKI Jakarta province.

Public-service in the context of "Smart City" should have been lower indeed than the traditional ones. However, first implementation will cost more, resulting technology implementation in "Smart City" needs bigger budgets in the beginning. These are the things that happened in big cities of countries that have just implemented smart city yet, such as Brazil. Hence, to improve efficiency and effectiveness of public-service application, also requires additional human resources and skill development, especially technological knowledge as in existed human resources (Diaz-Diaz et.all, 2017). The same thing also happened on the implementation of "Smart City" in all kelurahan of DKI 
Jakarta. The problem of insufficient input in responding people complaints should be balanced with an adequate budgets, appropriate number of employees and also skills.

In some countries that have implemented "Smart City", applications for complaints have indeed succeeded in increasing the efficiency and effectiveness of government publicservice to the community. However, some countries have also failed in implementing technology to public-services. They consider the community as the buyer and the government as the seller, where every purchased-service must be provided by the seller. Nevertheless, efficiency of public-services based on this application and technology, will be vary in every region, depending on the resources owned and the needs of the community (Shareef et.al, 2016). The same thing happened in Jakarta Smart City, every kelurahan has various efficiency rates, depending on the handled amount of input and output. The amount of input is consisted of number of employees in Kelurahan, number of PPSU, number of Satpol PP, and budgets of each Kelurahan. While the handled publicservices are problems of waste, illegal parking, illegal street-vendors, etc.

\section{CONCLUSION}

Progress of technology, information and communication gave birth to innovated development concept. One of the technology-based regional development concepts is the concept of Jakarta Smart City that uses technology innovation through application in doing public-services to the community. One of the utilized applications to improve public-services efficiency of DKI Jakarta government in 2016-2017 was QLUE. From the results of analysis in this study, it can be concluded that, first, in general, QLUE application has not been used properly by the people of DKI Jakarta as the form of government public-service performance, and tool of check-and-balance to the community. It can be seen from the minimum number of the people (2\%) of total people in DKI Jakarta that used QLUE application for reporting/complaining the circumstances of public facilities.

The performance of public services of DKI Jakarta government based on QLUE application in kelurahan is still inefficient. Based on analysis results of DEA, it is shown that there were only 74 kelurahan that reached efficient public-services performance over the last two years (2016-2017). The rest of those have not shown efficient performance, in fact a decrease of efficient performance in public-services occurred. Based on efficiency rates in 2016, there were 148 Kelurahan that the public-services were efficient, however it was decreasing drastically in 2017, remaining only 46 Kelurahan in the efficient category. It can be concluded that QLUE application has not worked optimally.

From the analysis results of slack rates, there was still an increase from input reduction rates and output addition in 2017 compared to 2016. Generally, the reduced input is the number of PPSU, number of employees in kelurahan, number of Satpol PP, and amount 
of budgets allocation. While the added output are the problems of waste, illegal advertising, violations, and public facilities. There were a greater number of employees in responding the reported people complaints, make it inefficient in following-up the complaints.

\section{REFERENCES}

Afonso, Antonio., Carla Scaglioni. (2005). Public Services Efficiency Provision in Italian Regions: A Non Parametric Analysis. ISEG-UTL Economics Working Paper No. 2/2005/DE/CISEP, pp: 1-25

Bush, Peter Andre., Helle Z., H., Oysen Saebo. (2018). Opportunitiees and Challenges of Digitized Discretionary practices: a public service worker perspective. Government Information Quartely, 2 547-556

Constantini, Valeria., Paolo Liberati. (2014). Technology Transfer, Institutions and Development. Technological Forecasting dan Social Change, 88, 26-48

Diaz-Dias, R., Munoz, L., Perez, G. D. (2017). Business model analisis of public services operating in the smart city ecosystem: The Case of SmartSantander. Future Generation Computer System, 76, 198-214

Fath-allah, A., et.al. (2014). E-government Maturity Models: A Comparative Study. International Journal of Software Engineering and Application, 5(3), 71-91

Fitriani, Widia Resti., Ikut Tri Handoyo., Puji Rahayu., Dana Indra Sensue. (2016). Intention to use Smart City System Based on Social Theory. Procedia of ICACSIS 16, 181-188

Govlab. (2016). Jakarta's Smart City Vision: A Megacity On A Mission. Delloitte: Singapore

Graham, Stepen. (2002). Bridging Urban Digital Divides? Urban Polarization and Information and Communications Technologies (ICTs). Urban studies, 39(1), 33-56

Hartley, J., Donaldson, C., Skelcher, C., \& Wallace, M. (2008). Managing to improve public services. Cambridge: Cambridge University Press.

Kamal, M., Vishanh, W., \& Zahir, I. (2010). Attitudinal and Behavioural Determinants Influencing Decision Makers When Adopting Integration Technologies in Local Government. Proceedings of the 43rd Hawaii International Conference on System Sciences (1-12). IEEE.

Kummitha, Rama Krishna Reddy., Nathalie Crutzen. (2017). How Do We understand Smart Cities? An Evolutionary Perspective. Cities, 67, 43-52

Oostveen, A dan Basselar, P.V. (2004). From Small Scale to Large Scale User Participation: A Case Study of Participatory Design in E-government System. Proceedings of The 8th Conference on Participatory Design 
Putri, Dinitia Adriana, Maharani Karlina CH, Jimmi Tanaya, Michael Canares. (2017). How Do Citizens Benefit From A Smart City? A Case Study of Jakarta Indonesia. A Research Paper. Woshington DC: World Wide Web Foundation

Rahmawati, Restu., Firman. (2017). Analisis implementasi Kebijakan Aplikasi QLUE di Wilayah Jakarta Utara. Sosial Politik Humaniora, 5(2), 386-404

Rondo-Brovetto P., Saliterer, I. (2007). Comparing Regions, Cities, and Communities: Local Government Benchmarking as an Instrument for Improving Performance and Competitiveness. The Inovation Journal: The Public Sector Innovation Journal, $12(3)$.

Shareef, M,A., Dwivedi, Y.K., Kumar, V., Kumar, U. (2016). Reformation of Public Service to meet citizens' needs as customers: Evaluating SMS as an alternative service delivery channel. Computers in Human Behavior, 61, 255-270

Yeh, Hsiaoping. (2017). The Effect of Successful ITC-Based Smart City services: From Citizens Perspektives. Government Information Quarterly, 34, 556-565

Ziadi, Ahmad Rizka. Supriyono, Bambang. Wijaya, Andy Fefta. (2016). The Effectiveness Of Information System In Public Complaint Service: An Implementation Of EGovernment Based On Jakarta Smart City Applications. International Journal of Management and Administrative Sciences (IJMAS) 